\title{
Staklo, od Antike do svemirskog doba
}

\author{
M. Čalogović* i T. Marjanac
}

ProGEO-Hrvatska, Horvatovac 102a, 10000 Zagreb

\begin{abstract}
Sažetak STEM-orijentirane nastave.

Ključne riječi

STEM, struktura, vrste, proizvodnja, svojstva stakla, pokusi, nastava kemije
\end{abstract}

Staklo je materijal koji se upotrebljava još od Antike pa sve do danas, ali je razvojem tehnologije postalo dostupno svima i sveprisutno je $u$ industriji. Za proizvodnju stakla važan je sastav sirovina, a svojstva stakla ovise i o procesu proizvodnje. $U$ članku je opisan proces proizvodnje stakla kroz povijest i razvoj novih vrsta stakla s boljim svojstvima. Također, uspoređeno je antropogeno s prirodnim staklima kao što su opsidijani i tektiti. Opisana su stakla koja se upotrebljavaju za izradu velikih teleskopa i u svemirskoj tehnologiji. U nastavnom dijelu opisani su jednostavni pokusi koji se mogu napraviti u učionici u sklopu

\section{Uvod}

Tko bi pomislio da se od čestih prirodnih materijala kao što su pijesak i pepeo može dobiti materijal bez kojeg se danas ne može zamisliti život? Naravno, riječ je o staklu. Kao što je nekada bilo kameno doba, pa potom željezno, danas se slobodno može reći da živimo u dobu stakla.

Teško je sa sigurnošću reći kad je staklo otkriveno, ali je već Plinije Stariji u 1. stoljeću Nove ere zapisao legendu o otkriću stakla (Naturalis Historiae, knj. 36, pogl. 65¹). Po Pliniju, nekoć je trgovački brod koji je prevozio prirodnu sodu (mineral trona**) pristao na neku pješčanu plažu da bi mornari pripremili obrok. Na plaži nisu našli kamenje na koje bi postavili kotao za kuhanje, pa su ga poduprijeli grumenjem sode s broda. Plamen je rastalio sodu koja se pomiješala s pijeskom, pa je potekla mornarima nepoznata transparentna taljevina - preteča stakla. ${ }^{2}$

lako se valjanost te legende često osporava, to je nedvojbeno prvi zapis o postanku stakla, a vjeruje se da je riječ o Feničkim trgovcima 5000 godina prije Nove ere.

Najstariji sačuvani stakleni predmeti su "perlice" u Feničanskim ogrlicama. U starom Egiptu i Rimu od stakla su izrađivali male vaze, kozmetičke posudice i nakit. Vrlo lije-

\footnotetext{
*Autor za dopisivanje: dr. sc. Marina Čalogović

e-pošta: mcalogovic06@gmail.com

** Trona je evaporitni mineral kemijske formule $\mathrm{Na}_{3} \mathrm{H}\left(\mathrm{CO}_{3}\right)_{2} \cdot 2 \mathrm{H}_{2} \mathrm{O}$. U prirodi se često pojavljuje u zajednici s drugim mineralima, kao što su gips, halit, natron i drugi (https://www.mindat.org/min-4031.html). U starom Egiptu trona se upotrebljavala u postupku mumifikacije.
}

pi primjerci antičkog stakla čuvaju se u zadarskom Muzeju antičkog stakla i u zagrebačkom Arheološkom muzeju.

Većina antičkog i srednjovjekovnog stakla sastoji se pretežno od oksida natrija, kalcija i silicija. Po sastavu, antičko staklo može se podijeliti na: a) stakla siromašna kalijem i magnezijem koja sadrže manje od 1,5 \% $\mathrm{K}_{2} \mathrm{O}$ i $\mathrm{MgO}$; i b) stakla bogata kalijem i magnezijem koja sadrže više od 1,5 \% $\mathrm{K}_{2} \mathrm{O}$ i $\mathrm{MgO}{ }^{3}$ Ta razlika u sastavu uzrokovana je sastavom sirovina koje su upotrijebljene za njegovu proizvodnju. Za proizvodnju stakla bogatih kalijem i magnezijem upotrebljavao se biljni pepeo bogat sodom $\left(\mathrm{Na}_{2} \mathrm{CO}_{3}\right)$ koji se dobivao sagorijevanjem halofilnih biljaka (halofita) sa slanih staništa. Takav pepeo bogat je sodom i 'živim' vapnom (CaO), a sadrži i znatne količine kalija i magnezija. Za proizvodnju stakla od takvih sirovina bilo je potrebno miješanje odgovarajućih udjela pepela i kvarcnog pijeska. Za proizvodnju stakla siromašnog magnezijem i kalijem upotrebljavan je mineralni izvor sode kao što je mineral trona iz Egipta. Soda se miješala s pijeskom koji je osim zrna kvarca sadržavao i odgovarajuću količinu vapnenačkih skeleta $^{* * * *}$ i njihovih ulomaka te zrna vapnenaca (koji se zagrijavanjem raspadaju i daju $\mathrm{CaO})$.

Miješanjem i taljenjem pepela s pijeskom bogatim kalcijevim karbonatom, nastalo je staklo bogato s $\mathrm{CaO}$ (i iz

\footnotetext{
*** Zainteresiranima preporučamo publikaciju "Pretpovijesni jantar i staklo" Arheološkog muzeja u Zagrebu iz 2006.

**** Vapnenački skeleti mogu biti izgrađeni od minerala aragonita, kalcita i željezovitog kalcita. Kalcit i aragonit su niskotemperaturni i visokotemperaturni polimorfi kalcijeva karbonata $\left(\mathrm{CaCO}_{3}\right)$. Kalcit kristalizira u heksagonskom, a aragonit u rompskom sustavu.
} 
pepela i iz pijeska). Takvo staklo teško se oblikovalo jer je zahtijevalo višu temperaturu obrade, a bilo je i sklono devitrifikaciji u kalcijev silikat.

Za proizvodnju stakla odgovarajuće kvalitete potreban je prikladan pijesak, a sastav Antičkog stakla prikazan je u Tablici 1. Većina obalnih morskih pijesaka nije prikladna za proizvodnju stakla jer takvi sadrže premalo $\mathrm{SiO}_{2}$, a previše $\mathrm{Al}_{2} \mathrm{O}_{3}$ ili $\mathrm{Fe}_{2} \mathrm{O}_{3}$ te premalo ili previše $\mathrm{CaO}$. Izrada stakla nije jednostavna jer pijesak i soda iz pepela sadrže nečistoće za koje se u davnini nije znalo, a utječu na svojstva stakla. Na primjer, nepoželjna je veća količina aluminijeva oksida i kalcijeva oksida premda je manja količina $\mathrm{CaO}$ poželjna jer sprječava kristalizaciju rastaljenog stakla. Veća količina $\mathrm{CaO}$ pak uzrokuje kristalizaciju sitnih kristalića zbog čega staklo gubi prozirnost.

Devitrifikacija je spontani rast kristala u staklu tijekom taljenja, formiranja stakla ili njegove obrade. ${ }^{4}$ Ta pojava može nepovoljno utjecati na optička svojstva, mehaničku čvrstoću, a ponekad i na kemijsku otpornost stakla. Ti nepoželjni kristali mogu rasti homogeno unutar stakla ili heterogeno na njegovoj površini. Ako se stakla predugo drže u kritičnom temperaturnom rasponu ili se presporo hlade, počet će kristalizacija, pa se neka stakla moraju hladiti veoma brzo da se izbjegne devitrifikacija.

Tablica 1 - Sastav antičkog i modernog stakla

Table 1 - Composition of Antic and modern glass

\begin{tabular}{c|c|c} 
& Antičko (Rimsko) staklo & Natrij-kalcij-silikatno staklo $^{6}$ \\
\hline $\mathrm{SiO}_{2}$ & $64.48-74.60$ & $60-80$ \\
\hline $\mathrm{Al}_{2} \mathrm{O}_{3}$ & $1.83-3.35$ & $0-3$ \\
\hline $\mathrm{Fe}_{2} \mathrm{O}_{3}$ & $0.00-1.58$ & $0-0.6$ \\
\hline $\mathrm{MgO}$ & $0.01-1.17$ & $0-6$ \\
\hline $\mathrm{MnO}$ & $0.00-2.21$ & $0-0.2$ \\
\hline $\mathrm{CaO}$ & $5.12-9.84$ & $7-14$ \\
\hline $\mathrm{Na}$ & $13.63-19.63$ & $9-15$ \\
\hline $\mathrm{K}_{2} \mathrm{O}$ & $0.27-1.23$ & $0-1.5$ \\
\hline $\mathrm{TiO}_{2}$ & $0.00-0.41$ & - \\
\hline $\mathrm{P}_{2} \mathrm{O}_{5}$ & $0.02-0.22$ & - \\
\hline
\end{tabular}

U Antici su se pri izradi stakla dodavali još neki minerali, kao što su (najvjerojatnije) stibnit $\left(\mathrm{Sb}_{2} \mathrm{~S}_{3}\right)$ i piroluzit $\left(\mathrm{MnO}_{2}\right)$, kako bi se postiglo da staklo bude bezbojno.?

Upotreba antičkog stakla za laboratorijske svrhe bila je ograničena, jer to staklo nije bilo otporno na nagle promjene temperature i imalo je lošu kemijsku otpornost. Tijekom 13. pa sve do 16. stoljeća proizvodnja stakla razvijala se u Veneciji i u Muranu, i tu se proizvodilo staklo bolje kvalitete. ${ }^{8}$ Priprema i pročišćavanje sirovine Venecijanskim staklarima osigurale su ujednačeni sastav sirovine, što je omogućilo proizvodnju stakla ujednačene kvalitete. Poka- zalo se da smanjenje udjela $\mathrm{Na}_{2} \mathrm{O}$, a povećanje udjela $\mathrm{CaO}$ ili $\mathrm{MgO}$ pridonosi većoj otpornosti na bazične i kisele otopine i smanjuje termičku ekspanziju stakla.

Početkom 19. st. postalo je jasno da je $\mathrm{CaCO}_{3}$ važan sastojak u proizvodnji stakla, jer se masovno počela upotrebljavati sintetska soda (čisti $\mathrm{Na}_{2} \mathrm{CO}_{3}$ ) koja ne sadrži nečistoće. Razvojem tehnologije taljenja povećana je kemijska otpornost stakla.

U današnje doba znanstvenici su otkrili da staklo ne mora biti silikatno i počela su se razvijati stakla od drugih tvari. Tako, na primjer, od 1960. znanstvenici uspijevaju proizvesti i metalno staklo koje zahtijeva vrlo veliku brzinu hlađenja (nekoliko stotina stupnjeva u sekundi) da bi se izbjegla kristalizacija. Metalno staklo je po sastavu legura od dvaju ili više metala koji imaju atome dosta različite veličine, pa imaju veliku viskoznost koja ograničava kretanje atoma i stvaranje pravilne kristalne rešetke. Takvo metalno staklo ima veliku čvrstoću, elastičnost i otpornost na koroziju.

\section{Sastav, struktura i svojstva stakla}

Staklo se dobiva kombinacijom mrežotvoraca (molekule ili oksidi elemenata koji mogu tvoriti staklenu 'mrežu'), modifikatora i intermedijara. Najčešći oksid u proizvodnji stakla je $\mathrm{SiO}_{2}$, a još se upotrebljavaju i $\mathrm{B}_{2} \mathrm{O}_{3}, \mathrm{P}_{2} \mathrm{O}_{5}$ i $\mathrm{GeO}_{2}$. Staklenu 'mrežu' može graditi samo jedan mrežotvorac ili kombinacija više njih, tako da postoje, npr., borosilikatna stakla. Neki metalni oksidi kao što je aluminijev oksid grade staklenu 'mrežu' u kombinaciji s nekim drugim mrežotvorcem.

Modifikatori staklene 'mreže' najčešće su oksidi alkalijskih i zemnoalkalijskih metala. Dodatkom $\mathrm{Na}_{2} \mathrm{O}$ ili $\mathrm{K}_{2} \mathrm{O}$ snižava se talište silikata, ali takva (natrij-silikatna) stakla nisu stabilna i topljiva su u vodi, ${ }^{*}$ pa se dodaje stabilizator kao što je $\mathrm{CaO}$. Iz sastava antičkog stakla može se vidjeti da su bogatija $\mathrm{s} \mathrm{Na}_{2} \mathrm{O}$ u usporedbi s modernim staklom (tablica 1) i zato su često predmeti od antičkog stakla korodirani. ${ }^{* *}$

Intermedijari predstavljaju stabilizatore staklene 'mreže'. Premalo stabilizatora daje staklu lošu kemijsku izdržljivost, a s previše stabilizatora staklo je pak sklono devitrifikaciji. Mali udio $\mathrm{Al}_{2} \mathrm{O}_{3}$ ili $\mathrm{MgO}$ poželjan je jer sprječava devitrifikaciju. Intermedijari koji se ugrađuju u staklenu 'mrežu' i stabiliziraju ju su $\mathrm{Al}_{2} \mathrm{O}_{3}, \mathrm{ZnO}$ i PbO. Dodatkom modifikatora $\mathrm{i}$ intermedijara smanjuje se viskoznost i snizuje se staklište (slika 1). ${ }^{9}$

\footnotetext{
*Primjer je takozvano 'vodeno staklo', vodena otopina natrijeva silikata koja se upotrebljava za šamotiranje, ali ima i primjenu u eksperimentu poznatom kao "kemijski" ili "silikatni vrt". O silikatnom vrtu možete čitati u Kemiji u industriji 69 (1-2) (2020) 43-46.

** Trošenje Antičkog stakla vidljivo je po njegovom površinskom obojenju, iridiscenciji koja je posljedica interferencije reflektiranog svjetla u korozijskom sloju.
} 


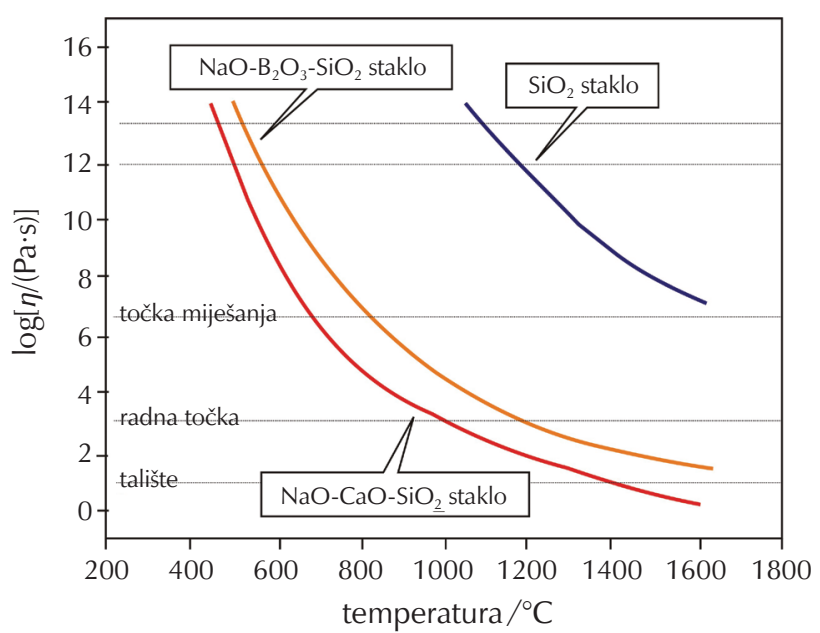

Slika 1 - Ovisnost viskoznosti o temperaturi za natrij-kalcij-silikatno, natrij-borosilikatno i kremeno staklo. Talište (na 10 Pa s): na toj točki staklo je dovoljno tekuće da se smatra tekućinom. Radna točka (na $10^{3}$ Pa s): staklo se može lako oblikovati i zato se obrada stakla provodi na toj točki. Točka mekšanja (4 $\cdot 10^{6}$ Pa s): predstavlja najvišu temperaturu na kojoj se s komadima stakla može baratati bez značajnih promjena dimenzije. Na toj točki staklo može teći pod svojom vlastitim težinom. Prilagođeno po ref. 9, str. S-138.

Fig. 1 - Viscosity vs. temperature curves for sodium-calcium-silicate, sodium-borsilicate and silica glass. Melting point (at $10 \mathrm{~Pa} \mathrm{~s}$ ): At this point, the glass becomes fluid enough to be considered a liquid. Working point (at $10^{3} \mathrm{~Pa} \mathrm{~s}$ ): Glass is easily deformed at this viscosity, which is why glass is fabricated at this point. Softening point (4.106 Pa s): Represents the maximum temperature at which a glass piece may be handled without significant dimensional changes. At this point, glass can flow under its own weight. Modified after Ref. 9, p. S-138.

Temperatura pri kojoj dolazi do faznog prijelaza - staklište može ovisiti i o brzini hlađenja. Ako je hlađenje sporo, taljevina ima više vremena za opuštanje i staklište je na nižoj temperaturi, a proizvedeno staklo ima veću gustoću (slika 2). ${ }^{10}$ Vrlo sporim hlađenjem pak može doći do kristalizacije, pa možemo reći da je staklo metastabilno stanje tvari. Kristalizacija je termodinamički prijelaz, a staklište je kinetički.

Za nastanak stakla važan je omjer početnih komponenti (sastojaka). Molekule ili ioni se u taljevini vežu u mrežu, i ako se ona hlađenjem ne može organizirati u pravilnu strukturu, nastaje krutina koja ima uređenje kratkog dosega kao što je staklo. Ioni $\mathrm{Na}^{+}, \mathrm{K}^{+}, \mathrm{Mg}^{2+}, \mathrm{Ca}^{2+} \mathrm{u}$ strukturi se ponašaju kao nečistoće koje sprječavaju nastanak kristalne strukture.

Oksidi tvore staklenu 'mrežu' u kojoj su koordinacijski poliedri (metalni centri s kisikovim atomima) povezani vrhovima, a ne bridovima ili plohama. U staklenoj 'mreži' kisikov atom vezan je na najviše dva druga atoma te se takav atom naziva premošćujući. Dodatkom modifikatora u staklenoj mreži javljaju se nepremošćujući kisikovi atomi i nastaju šupljine u strukturi u koje se ugrađuju metalni kationi (slika 3). ${ }^{11}$

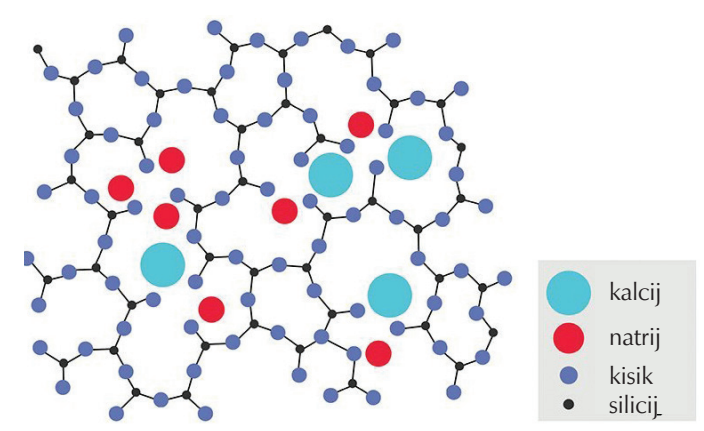

Slika 3 -2D prikaz strukture natrij-kalcij-silikatnog stakla. Prilagođeno po ref. 11.

Fig. 3 -2D representation of sodium-calcium-silicate glass structure. Modified after Ref. 11.

Vezanje modifikatora u staklenu (silikatnu) mrežu:

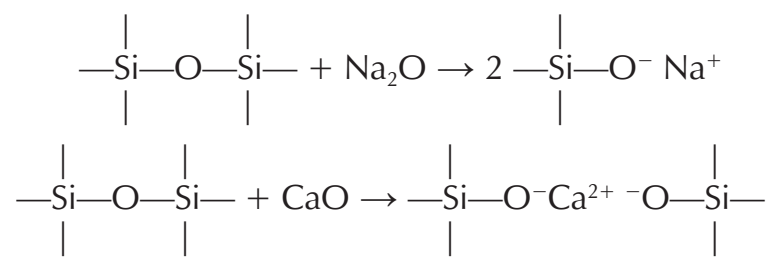

Otapanje površine stakla (hidratacija):

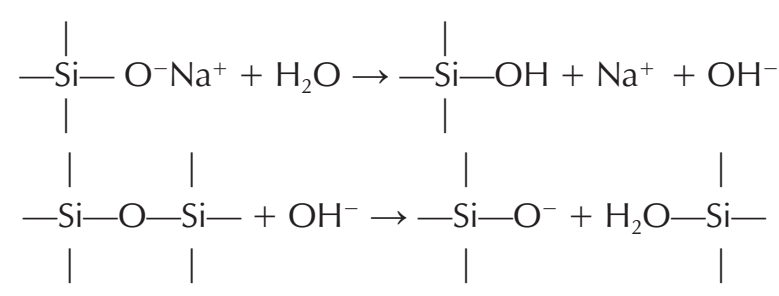

Staklo i kristalna tvar mogu se lako razlikovati usporedbom njihovih rendgenskih difraktograma. $U$ difraktogramu kristala vide se dobro definirani signali na kristalografski određenim pozicijama, dok se kod difraktograma stakla vidi široko razvučeni signal (slika 4), ${ }^{12}$ što je svojstveno za amorfne materijale, jer se opaža sređenost atoma samo na malim međusobnim udaljenostima.

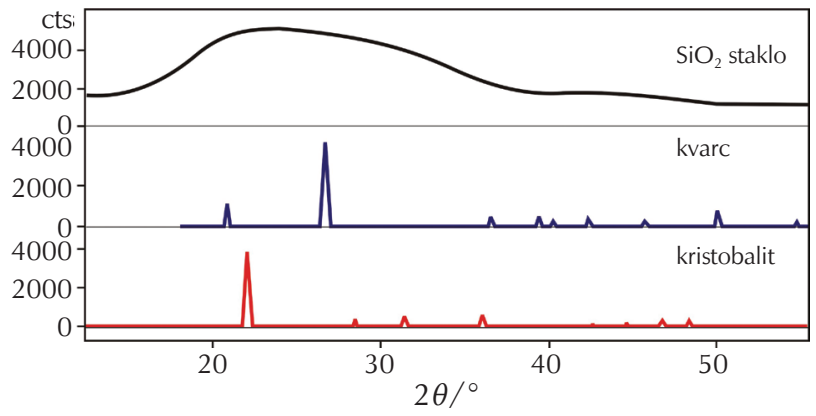

Slika 4 - Difraktogrami za silikatno staklo, kvarc i kristobalit. Prilagođeno po ref. 12.

Fig. 4 - Diffractograms of silicate glass, quartz, and crystoballite. Modified after Ref. 12. 
Tvrdoća stakla ovisi o jačini veza i gustoći pakiranja atoma u strukturi. Na Mohsovoj skali* tvrdoće, oksidna stakla nalaze se u rasponu od 5 do 7 . Tvrdoća stakla je veća od, primjerice, kalcita, a manja od kvarca, pa se struganje po staklu često primjenjuje za jednostavno razlikovanje fragmenata ta dva minerala.

Struktura, boja i svojstva stakla ovise o metalnim ionima koji mogu biti nečistoće u sirovini ili mogu biti dodani namjerno. Kao bojilo stakla upotrebljavale su se soli različitih metala, npr., Co za plavu boju, a Cu za zelenu boju. ${ }^{13}$ Željezni oksidi često su nečistoće u pijesku i staklu mogu dati zelenkastu ili plavkastu boju. Tako boju antičkog stakla daje koncentracija i oksidacijsko stanje željeza. Ako se u taljevinu stakla koje sadrži Fe ${ }^{2+}$ ione (koji daju plavozelenu boju) doda oksid antimona ili mangana, ioni željeza se reduciraju u $\mathrm{Fe}^{3+}$ koje staklu daje žutu boju (slika 5). ${ }^{14}$

$$
\begin{aligned}
& 2 \mathrm{Fe}^{2+}+\mathrm{Sb}^{5+} \rightleftharpoons 2 \mathrm{Fe}^{3+}+\mathrm{Sb}^{3+} \\
& \mathrm{Fe}^{2+}+\mathrm{Mn}^{3+} \rightleftharpoons \mathrm{Fe}^{3+}+\mathrm{Mn}^{2+}
\end{aligned}
$$

Ako su u staklu prisutni oksidacijski i redukcijski uvjeti u određenom omjeru, dobije se bezbojno staklo. ${ }^{15}$ Kad se doda manganov oksid, ljubičasta boja koju daju $\mathrm{Mn}^{3+}$ ioni kompenzira žutu boju $\mathrm{Fe}^{3+}$ iona (ljubičasta i žuta su komplementarne boje koje miješanjem u jednakom omjeru daju bijelu svijetlost).

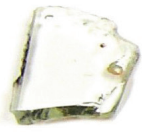

oksidirano

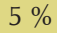

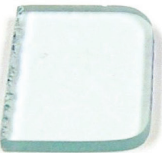

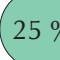

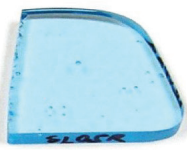

reducirano

$99 \%$
Slika 5 - Natrij-kalcij-silikatna stakla s različitim oksidacijskim stanjima željeza $\left(\mathrm{R}=\left[\mathrm{Fe}^{2+}\right] /\left(\left[\mathrm{Fe}^{2+}\right]+\left[\mathrm{Fe}^{3+}\right]\right)\right)$. Prilagođeno po ref. 15.

Fig. 5 - Sodium-calcium-silicate glasses with different iron oxidisation stages $\left(\mathrm{R}=\left[\mathrm{Fe}^{2+}\right] /\left(\left[\mathrm{Fe}^{2+}\right]+\left[\mathrm{Fe}^{3+}\right]\right)\right)$. Modified after Ref. 15.

\section{Vrste stakla}

\section{Prirodna stakla}

Najčešće staklo u prirodi je opsidijan koji nastaje brzim hlađenjem lave u dubokom moru. Opsidijan može biti različitih boja, pa poznajemo, npr., crni i smeđi varijetet (slika 6A). ${ }^{16}$ Mnogi opsidijani nisu homogeni, pa sadrže sitne plinske uklopke u obliku malih mjehurića i sitne kristaliće drugih minerala (slika 6B). U prirodi se mogu naći i fulguriti, staklene cjevčice koje nastaju prilikom udara munje u pijesak ili pješčano tlo (slika 7) te tektiti - grumeni ili kaplji-

\footnotetext{
* Mohsova skala tvrdoće je empirijska ljestvica u kojoj su minerali svrstani po njihovoj tvrdoći u rasponu od 1 do 10 . Svaki mineral s višom tvrdoćom može zagrepsti površinu onog prethodnog. U Mohsovoj skali najmekši mineral je talk s tvrdoćom 1, a slijede gips, kalcit, fluorit, apatit, ortoklas, kvarc, topaz, korund i najtvrđi je dijamant s tvrdoćom 10.
}

ce koje nastaju taljenjem stijena prilikom udara asteroida i brzim hlađenjem kapljica te taljevine u atmosferi (slika 8A). Zanimljivo je znati da su i tektiti podložni devitrifikaciji i koroziji kao i antropogena stakla. Na primjer površina vrlo dekorativnih tektita iz Češke (takozvani moldaviti) (slika $8 \mathrm{~B})^{20}$ izrazito je korodirana, pa ne odražava njihov izvorni oblik. Nabrojene vrste prirodnih stakala su makroskopskih veličina, ali u prirodi se mogu naći i staklene čestice mikroskopskih dimenzija, npr., sferule i mikrotektiti, koji su nađeni u sedimentima različite starosti i kod nas. ${ }^{21}$
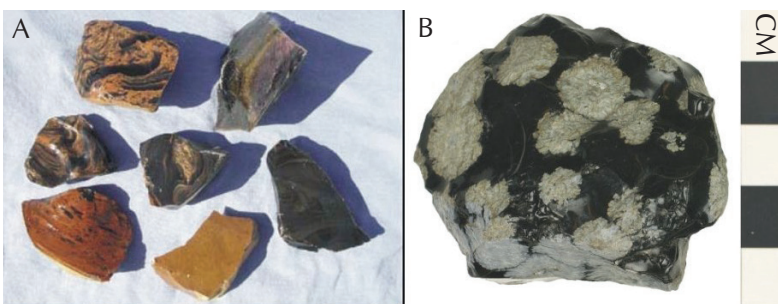

Slika 6 - A: Opsidijani različitih boja (ref. 16), B: "pahuljičasti" opsidijan (ref. 17)

Fig. 6 - A: Differently colored obsidians (Ref. 16), B: "snowflake" obsidian (Ref. 17)

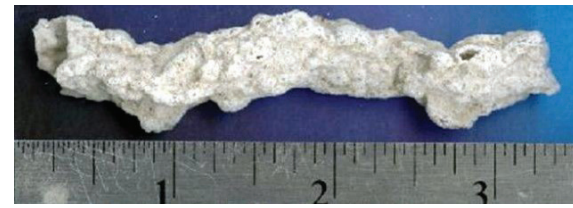

Slika 7 - Fulgurit (ref. 18)

Fig. 7 - Fulgurite (Ref. 18)
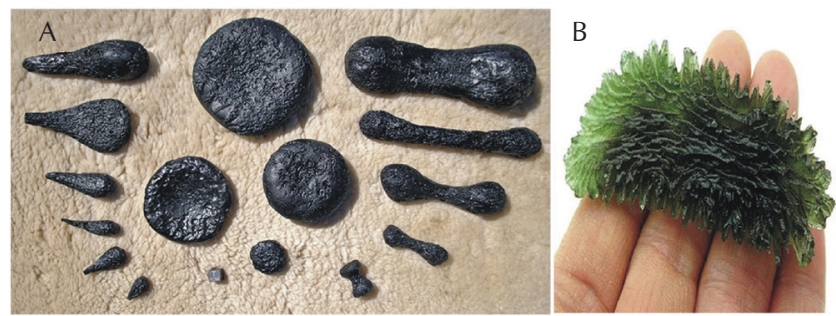

Slika 8 - A: Tektiti iz Indokine (ref. 19); B: tektit iz Češke, moldavit (ref. 20)

Fig. 8 - A: Tektites from Indochina (Ref. 19); B: Tektite from Czechia, moldavite (Ref. 20)

\section{Prozorsko staklo}

Najzastupljenija vrsta stakla poznata svim laicima je prozorsko koje je najčešće po sastavu natrij-kalcij-silikatno staklo. Prozorsko staklo poznato je od davnina, ali se tada proizvodilo drugačije nego danas. Staklene ploče za ugradnju u prozore proizvodilo se u osnovi istim postupkom kao i ambalažno staklo. Staklopuhači su komad rastaljenog stakla oblikovali u velik balon upuhivanjem zraka kroz dugu cijev. Zatim su balon spljoštili i vrlo brzo ga vrtjeli da bi po- 
stigli velik plosnati disk. Međutim, takvo staklo nije imalo ujednačenu debljinu, a ograničenje je bila i veličina staklene ploče koja se tako mogla proizvesti. Zato su se prozori nekad radili od mnogo manjih staklenih pločica koje su bili povezane olovom. Kasnije je razvijena tehnika izrade staklenih ploča od staklenih cilindara koje su također proizvodili staklopuhači. Stakleni cilindri su se potom rezali i ponovno zagrijavali dok se staklo nije izravnalo u staklenu ploču. Tom tehnikom neke tvornice i danas proizvode ukrasna stakla.

Današnja prozorska stakla proizvode se lijevanjem rastaljenog stakla u bazen ispunjen rastaljenim kositrom, float-postupkom koji je 1959. razvila britanska tvrtka Pilkington Brothers. Te se taljevine ne miješaju zbog razlike u gustoći, a na taj se način mogu postići gotovo savršeno ravne i glatke velike staklene ploče ujednačene debljine.

\section{Kristalno (olovno) staklo}

Na prvom mjestu treba istaknuti da naziv "kristalno staklo" ne potječe od njegove kristalne strukture, nego je nastao u vrijeme kada su staklari u Muranu kod Venecije izrađivali staklene ukrase koji su sličili na kvarc, a tada se kvarc nazivao cristallo. To staklo moglo se uspješno oblikovati i brusiti u dekorativne staklene predmete koje je odlikovao visoki sjaj.

Najstariji primjer stakla s primjesom olova je plavo staklo koje potječe iz Mezopotamije, a datirano je na 1400 godina prije Nove ere i sadrži 3,66 \% PbO. Olovo je u antičkom staklu zastupljeno u malim količinama, tj. manje od $10 \%$, što upućuje na to da nije bilo dodano kao modifikator za snižavanje tališta, nego najvjerojatnije za boju stakla. I u srednjem vijeku olovo se dodavalo za bojenje stakla. Tek je u 17. stoljeću Englez George Ravencroft* započeo industrijsku proizvodnju olovnog stakla. ${ }^{22}$ To staklo se još naziva i flintsko staklo, jer su se tada kao izvor silikata upotrebljavale nodule kremena (engl. flint). Ravencroft je otkrio da se dodavanjem olova tijekom taljenja stakla povećala njegova kvaliteta i da se takvo staklo može lakše taliti i oblikovati. U olovnom staklu $\mathrm{CaO}$ zamijenjen je s PbO kojeg sadrži minimalno $24 \%$. Dodatkom olovnog oksida poveća se indeks loma stakla i snizuje se njegova viskoznost te radna temperatura pri kojoj se talina može oblikovati. Vlasnici starih vaza od kristalnog stakla mogu se osvjedočiti da je to staklo nepostojano.

\section{Vatrostalna stakla}

Vatrostalna stakla razvijena su početkom 20. stoljeća da bi se proizvelo staklo koje može izdržati nagle promjene temperature, a zasluga pripada Nijemcu Ottu Schottu. ${ }^{* *}$ Naime, do tad staklo nije podnosilo velik temperaturni šok, pa su se događale željezničke nesreće. Staklene ploče na acetilenskim lanternama koje su se nalazile na tadašnjim lokomotivama jako bi se ugrijale od topline plamena, ali

\footnotetext{
* George Ravencroft (1618. - 1681.) bio je engleski industrijalac koji je osnovao tvornicu stakla u Londonu 1673. g.

** Friedrich Otto Schott (1851. - 1935.) bio je njemački kemičar, tehnolog stakla u Jeni i izumitelj borosilikatnog stakla
}

bi hladna kiša izazvala naglo hlađenje i pucanje stakla te gašenje svjetiljke. Taj je problem riješen zamjenom većine $\mathrm{Na}_{2} \mathrm{O}$ u staklu $\mathrm{s}_{2} \mathrm{O}_{3}$. Tako dobiveno staklo sadrži od 5 do $13 \% \mathrm{~B}_{2} \mathrm{O}_{3}$ i može izdržati promjenu temperature od $200{ }^{\circ} \mathrm{C}$. Danas se borosilikatno staklo upotrebljava za većinu staklenog pribora u laboratoriju, ali i u kućanstvu, a poznato je pod tržišnim imenom Pyrex. Borosilikatna stakla imaju iznimno nizak koeficijent toplinske ekspanzije, što ih čini otpornijima na toplinski šok od ostalih stakala. Najveći proizvedeni komad borosilikatnog stakla je zrcalo promjera 5,1 m i teško 18 t, koje je 1949. ugrađeno u Haleov teleskop na zvjezdarnici Mount Palomar u SAD-u. Zbog izuzetnih dimenzija, prvo lijevanje stakla u kalup nije bilo uspješno, pa je staklo za zrcalo izrađeno tek u drugom pokušaju 1934. Hlađenje stakla potrajalo je 10 mjeseci, nakon čega je brušeno punih 11,5 godina, s prekidom od 5 godina zbog Drugog svjetskog rata. $U$ brušenju je odstranjeno čak 4,5 t stakla, da bi se postigao konkavni parabolični oblik s preciznošću od $50 \mathrm{~nm}$.

Još veću otpornost na toplinski šok i kemijsku izdržljivost ima alumosilikatno staklo koje sadrži $5-10 \% \mathrm{Al}_{2} \mathrm{O}_{3}$. Alumosilikatno staklo ima takvu otpornost da se može upotrebljavati izravno na grijačem elementu štednjaka. Upotrebljava se i za posebne bočice za tekuće farmaceutske preparate, ali i za staklene niti od kojih se proizvodi staklena tkanina za 'fiberglas'.***

Staklo bogato $\mathrm{SiO}_{2}(96,5$ - 100 \%), tzv. kvarcno staklo teško se proizvodi zbog visoke temperature tališta čistog $\mathrm{SiO}_{2}$. Međutim, proizvodi se za posebne primjene zbog svoje izvanredne izdržljivosti, toplinske i kemijske otpornosti te svojstva da propušta ultraljubičastu svjetlost. Zbog male termičke ekspanzije ugrađuje se u prozore svemirskih brodova i batiskafa, laboratorijske instrumente i detektore, specijalne reflektore, halogene svjetiljke i sve druge predmete koji su izloženi velikim temperaturnim oscilacijama. Prozori na svemirskim brodovima izrađeni od kvarcnog stakla mogu izdržati temperature čak do $1200{ }^{\circ} \mathrm{C}$.

\section{Koliko se stakla proizvodi i reciklira?}

Staklo se kao prastari materijal i dalje razvija da bi se zadovoljile nove visokotehnološke potrebe kako na Zemlji tako i u svemiru. Koliko je staklo važan materijal pokazuje podatak da se godišnje u svijetu proizvede 209 milijuna tona stakla, od čega je 106 milijuna tona ravnog stakla, a ostalo se upotrebljava za posuđe i kućanske proizvode. ${ }^{23}$ Da bi se istaknulo koliko bitnu ulogu staklo ima u društvu, 2022. godina proglašena je Međunarodnom godinom stakla (slika 9), a za više informacija pogledajte ovu poveznicu: https://iyog2022.org/.

\footnotetext{
*** Fiberglas (stakloplastika) je kompozitni materijal od staklenih niti međusobno povezanih sintetskom smolom. Ima dobra mehanička svojstva i otporan je na kemijske utjecaje pa se upotrebljava u brodogradnji, industriji i izradi sportske opreme. Procjenjuje se da je 2001. godine preko 50 milijuna kilograma fiberglasa upotrijebljeno za proizvodnju lopatica vjetroturbina.
} 


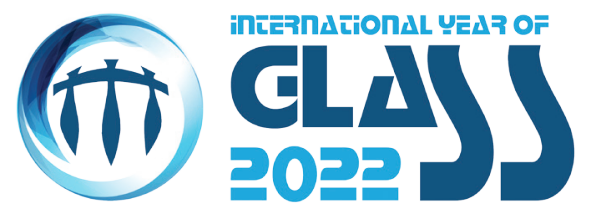

Slika 9 - Logotip Međunarodne godine stakla (ref. 23)

Fig. 9 - International Year of Glass logo (Ref. 23)

U današnje vrijeme vrlo je važna reciklaža otpada, a staklo se može uspješno reciklirati usitnjavanjem, taljenjem i oblikovanjem u nove proizvode. Prema podatcima iz 2018., u Europskoj uniji reciklira se u prosjeku oko $76 \%$ ambalažnog stakla, a u SAD-u oko $33 \%$, ali je raspon među saveznim državama velik.

\section{Primjena u nastavi}

Staklo je zahvalan materijal za izvođenje različitih pokusa kojima se dokazuju njegova svojstva. U nastavku slijedi nekoliko jednostavnih pokusa koji se mogu demonstrirati na nastavi kemije.

Topljivost ambalažnog stakla u vodi može se predočiti jednostavnim pokusom gdje se stakleni prah stavi u malo destilirane vode i zatim kuha nekoliko minuta. ${ }^{24,25}$ Dodatkom otopine fenolftaleina, vodena otopina se oboji ljubičasto, što ukazuje na to da je otopina lužnata i da se stakleni prah otapa u vodi.

Električna vodljivost stakla može se demonstrirati zagrijavanjem staklene cjevčice koja povezuje elektrode spojene na bateriju i žarulju. Staklo koje je na sobnoj temperaturi izolator pri povišenoj postaje provodno za električnu struju pa žarulja zasvjetli. ${ }^{24,25}$

Prisutnost olova u "kristalnom" staklu može se dokazati tako da se usitni komad kristalne čaše i dobiveni stakleni prah kratko kuha u otopini natrijeva ili kalijeva hidroksida. Zatim se u ohlađenu otopinu doda nekoliko kapi otopine natrijeva sulfida. Nastaje crni talog olovnog sulfida koji dokazuje olovo u ispitivanom uzorku stakla. ${ }^{24,25}$

Tema za raspravu s učenicima može biti hipoteza o fluidalnom karakteru stakla, to jest, pitanje je li staklo krutina ili poseban tip tekućine. Opažanje da su stara stakla na crkvenim prozorima različito debela, navelo je neke istraživače na to da staklo interpretiraju kao pothlađenu tekućinu koja neprimjetno i dalje teče. Razlog tog opažanja već je gore opisan, a posljedica je tadašnjeg načina izrade staklenih ploča. Treba napomenuti da zadebljanje stakla zbog tečenja nikad nije dokazano. Danas se dovoljno zna o svoj- stvima stakla da se može tvrditi da je staklo ipak krutina. Iz slike 1 se vidi da je ovisnost viskoznosti o temperaturi neprekidna, pa se smatra da taljevina hlađenjem prelazi u staklo pri viskoznosti od $10^{12} \mathrm{~Pa} \mathrm{s.}{ }^{26} \mathrm{Na}$ tom grafu nema faznog prijelaza pri temperaturi staklišta. Pri toj viskoznosti mehanička svojstva materijala postaju jako slična krutini.

Svaki student kemije ima priliku na praktikumu steći osnove oblikovanja stakla izvlačenjem kalipare i savijanjem cjevčice. Koliko je za kemičara važno znati oblikovati staklo, vidi se na primjeru poznatog kemičara J. J. Berzeliusa s početka 19. st., koji je izučio i staklarski zanat da bi sam mogao izrađivati svoj pribor za pokuse kojima je odredio atomske težine elemenata. ${ }^{27}$

\section{Zaključak}

Staklo je jedan od najstarijih umjetnih materijala koji ima sve veći značaj i primjenu. Razvoj novih tehnologija omogućuje nov i ubrzan razvoj tehnologije izrade stakla s novim izuzetnim svojstvima, kao što je otpornost na visoke temperature, visoka mehanička otpornost, prozirnost za određene valne dužine elektromagnetskog zračenja, svojstvo kontroliranog lomljenja, visoka apsorpcija radioaktivnog zračenja itd. Danas je staklo našlo primjenu u vrlo različitim predmetima svakodnevne uporabe, npr., u pećnicama, grijaćim pločama, zaslonima televizora i računala, modernim telefonima, vozilima svih vrsta, solarnim kolektorima, optičkim uređajima itd. Moderni svijet ne može se zamisliti bez stakla koje danas uspješno zamjenjuje druge stare materijale poput metala. Razvoj stakla s posebnim svojstvima sigurno će se nastaviti i u budućnosti, pa je sasvim opravdano reći da živimo u dobu stakla.

\section{Literatura}

\section{References}

1. URL: http://www.perseus.tufts.edu/hopper/text?doc $=$ Perseus\%3Atext\%3A1999.02.0137\%3Abook\%3D36\%3Achapter\%3D65 (2. 6. 2021.).

2. D. Grdenić, Povijest kemije, Novi liber i Školska knjiga, Zagreb, 2001., str. 37-39.

3. I. C. Freestone, M. J. Hughes, C. P. Stapleton, The Composition and Production of Anglo-Saxon Glass, Catalogue of Anglo-Saxon Glass in the British Museum, 2008., str. 29-46.

4. M. Grayson (ur.), Encyclopedia of glass, ceramics, clay and cement, John Wiley \& Sons, New York, 1985., str. 475.

5. D. Brems, P. Degryse, M. Ganio, S. Boyen, The production of Roman glass with western Mediterranean sand raw materials: preliminary results, Eur. J. Glass Sci. and Technol. A $\mathbf{5 3}$ (2012) 129-138.

6. URL: http://glassproperties.com/glasses/ (20. 4. 2021.).

7. I. C. Freestone: Pliny on Roman Glassmaking, u: M. Martinon-Torres, T. Rehren (ur.): Archaeology, History and Science, Publ. Institute of Archaeology, University College London, 
Walnut Creek, CA: Left Coast Press, 2008., str. 77-100.

8. S. C. Rasmussen, Advances in $13^{\text {th }}$ century glass manufacturing and their effect on chemical progress, Bull. Hist. Chem. 33 (1) (2008) 28-34, url: http://acshist.scs.illinois.edu/bulletin_open_access/v33-1/v33-1\%20p28-34.pdf.

9. W. D. Callister Jr., Fundamentals of Material Science and Engineering, John Wiley \& Sons, New York, NY, USA, 2001.

10. P. Gibbs, Is glass liquid or solid?, URL: https://math.ucr.edu/ home/baez/physics/General/Glass/glass.html.

11. URL: https://www.koppglass.com/blog/3-common-glass-types-properties-and-applications (2021.)

12. URL: https://www.iitk.ac.in/che/pdf/resources/XRD-reading-material.pdf (2021.)

13. S. Saminpanya, C. Saiyasombat, N. Thammajak, C. Samrong, S. Footrakul, N. Potisuppaiboon, E. Sirisurawong, T. Witchanantakul, C. Rojviriya, New Light on Ancient Glass Beads by Synchrotron, SEM-EDS, and Raman Spectroscopy techniques, Sci. Rep. 9:16069 (2019) 1-12, doi: https://doi. org/10.1038/s41598-019-52322-2.

14. A.-I. Bidegaray, K. Nys, A. Silvestri, P. Cosyns, W. Meulebroeck, H. Terryn, S. Godet, A. Ceglia, 50 shades of colour: how thickness, iron redox and manganese/antimony contents influence perceived and intrinsic colour in Roman glass, Archaeol. Anthrop. Sci. 12 (2020) 1-17, doi: https://doi. org/10.1007/s12520-020-01050-0.

15. V. Velcamer, Spectroscopic and Structural Properties of Iron in Silicate Glasses. Disertacija, Univ. Pierre i Marie Curie, Pariz, 2016., 236 str.

16. URL: https://geology.com/rocks/obsidian.shtml (8. 6. 2021.).
17. URL: https://collections.nmnh.si.edu/search/ (29. 6. 2019.).

18. URL: https://webecoist.momtastic.com/2009/11/03/fulgurites-high-glass-digs-where-lightning-goes-to-die/ (30. 9. 2015.).

19. URL: https://www.meteorite-times.com/part-one-indochinites-the-classics/ (8. 6. 2021.).

20. URL: http://www.geologyin.com/2018/03/what-is-moldavite-and-how-to-spot-fake.html (8. 6. 2021.).

21. M. Čalogović, Elementna i strukturna analiza impaktom rastaljenih stijena i staklenih sferula. Disertacija, Prirodoslovno-matematički fakultet Sveučilište u Zagrebu, 2020., 112 str.

22. C. R. Kurkjian, W. R. Prindle, Perspectives on the history of glass composition, J. Amer. Ceramic Soc. 81 (4) (1998) 795-813, doi: https://doi.org/10.1111/j.1151-2916.1998. tb02415.x.

23. Towards an International Year of Glass in 2022, URL: https:// docs.google.com/viewer?url=https $\% 3 \mathrm{~A} \% 2 \mathrm{~F} \% 2 \mathrm{Fwww}$. iyog 2022 .org\% 2 Fimages\% 2 Ffiles $\% 2$ F 77 -economicsiyog-200925.pdf (3. 6. 2021.).

24. M. Sikirica, Zbirka kemijskih pokusa, Školska knjiga, Zagreb, 2011., str. 552-555.

25. M. Sikirica, Metodika nastave kemije, Školska knjiga, Zagreb, 2003., str. 378-381.

26. M. I. Ojovan, Viscosity and glass transition in amorphous oxides, Adv. Cond. Matt. Phys. (2008) 1-23, doi: https://doi. org/10.1155/2008/817829.

27. N. Raos, Relativna atomska masa - što je to?, Kem. Ind. 70 (5-6) (2021) 317-324, doi: https://doi.org/10.15255/ KUI.2018.042. 


\section{SUMMARY}

\section{Glass, from Antiquity to the Space Age}

Marina Čalogović* and Tihomir Marjanac

Glass has been produced since ancient times, and today is a high-technology material embedded in almost every technical product. This article describes how ancient glass was produced, and how the technology evolved developing new types of glass with ever better properties. Fabricated glass is compared with natural glass such as obsidian and tektite. The versatile use of glass today spans from flat window glass to heat-resistant Pyrex glass, which was used for the primary mirror of the large telescope on Mt. Palomar observatory, and in space technology. The education section describes several easy experiments, which may be conducted in Chemistry classes.

\section{Keywords}

STEM, structure, types, production, properties of glass, experiments, chemistry education

ProGEO-Hrvatska

Review

Horvatovac $102 a$

10000 Zagreb, Croatia

Received June 16, 2021 Accepted October 15, 2021 